\title{
Relationship between School Quality and Students' Performance in Selected Schools of Nursing in South-Western Nigeria
}

\author{
Mary Idowu Edward, Rn, M.Sc Nursing \\ Ondo State School of Nursing, Igbatoro Road, Akure, Ondo State.
}

\begin{abstract}
Introduction: The purpose of Schools of Nursing is to produce quality nurses with knowledge and practical skills with abilities of competing in the labour market. The Nursing and Midwifery Council of Nigeria (NMCN) expectation of good performance in Nursing and Midwifery Council Qualifying Examination (NMCQE) is between $90 \%$ and $100 \%$ consistently. Disappointedly, the result of NMCFQE for the past 5 years did not reach this set standard. Some schools scored even below 50\%. Different factors including school quality $(S Q)$, educational background, intelligence, learning abilities, attitudes, among other variables influence learning outcomes. This study investigated school quality (SQ) which describes what is available in Schools of Nursing as teaching-learning resources in relation to student academic performance (SP).

Methods: The descriptive correlative design method was used in the study with a target population of sixteen (16) Schools of Nursing in South-Western Nigeria. Purposive and stratified random techniques were used to select 12 Schools of Nursing out of sixteen (16) schools. The schools were stratified as Federal Government Schools (FGS), State Government Schools (SGS) and Mission Schools (MS). Random sampling was utilized to select schools that are more than one under each of the establishing authority while purposive sampling was used to select a school that is the only one under an establishment. The instrument for data collection was researcher's designed School Quality Assessment Checklist (SQAC) using four quality indicators of World Bank School Quality Model (1991). The Quality Indicators (QI) are Teachers' Quality Indicators (TQI), Physical and Material Quality Indicators (PMQI), Finance Quality Indicators (FQI) and Resources Management and Organization Quality Indicators (RMOQI). Pearson Moment Correlation statistical package was used to analyse the data. Correlation Coefficient was computed between the results of the School Quality Indicators (SQI) and 5years results of NMCQE in the Schools under study. Three hypotheses were raised and tested at 0.05 level of significance.

Results: Findings revealed that there is positive insignificant relationship between $S Q$ (mean: $87 \pm 4.8$ ) and $S P$ (mean: $76 \pm 10$ ), $r=.29 p>0.05$; TQ (mean: $16.4 \pm 2$ ) and $S P$ (mean: $76 \pm 10$ ), $r=.23 p>0.05$; PMRQI (mean: $41 \pm 4.4$ ) and $S P$ (mean: $76 \pm 10$ ), $r=.32 p>0.05$; FQI (mean: $12 \pm 1.6$ ) and $S P($ mean: $76 \pm 10$ ), $r=.06$ $p>0.05$. There was a negative insignificant relationship between RMOQI (mean: $18 \pm 3.4$ ) and SP (mean: $76 \pm$ 10), $r=-.15 p>0.05$. A significant difference exists between SP in the FGS (mean: $83 \pm 3.2$ ); SGS (mean: $67.7 \pm$ 7.3) and MS (mean: $80.2 \pm 8.5$ ) $p<0.05$. There is no significant difference between SQ in FGS (mean: $90 \pm 6$ ), $S G S$ (mean: $84.4 \pm 6.2$ ); and $M S$ (mean: $88 \pm 2.6$ ) $p>0.05$.

Conclusion: It was confirmed that weak relationships exist between $S Q$ and $S P$ in the schools under study. It is therefore recommended that concerted efforts be made to improve the School Quality Indicators (SQI) which will invariably improve students' performance (SP) in Schools of Nursing.
\end{abstract}

Key Words: School quality, school quality indicators, students' performance, school quality indicator model

\section{Introduction}

The scope of healthcare delivery is rapidly changing and nursing profession must keep pace with the changes. In order to ensure this, Schools of Nursing have a role to play in ensuring delivery of quality nursing education to student nurses. However, one of the factors that can ensure delivery of quality nursing education is high school quality. It is believed that high school quality will enhance students learning and their performance in examinations. The purpose of any school, nursing school inclusive is to produce quality students that are equipped with knowledge and practical skills as well as the capability of competing in the labour market. Schools of Nursing in particular strife to maintain standard of training set by the Nursing and Midwifery Council of Nigeria. Attempts have been made and are still being made to find out the contributing factors affecting the efforts of the schools in producing students that will perform excellently in the final examination and in eventual practice. Literature abounds (Oladokun, 2008, Amoo, 2006; Smendon \& Cromen, 2004, Burgin, 2003;) with various research findings all putting forward hypotheses, suggestions, and ideas about the factors influencing students' performances in examinations. Some of these factors are School Quality, students' educational background, intelligence, attitude of the students, financial background of the students' age maturity, sex and many others (Hijaz \& Raza-Navgi, 2006, Hanushek, 2005, Geleto, 2004). 
School quality includes among others resources made available in the school for effective teaching learning process to enhance students' academic performance. These resources are human resources, physical and material resources, finance, management and organization resources. Performance is the extent to which the students and school as a whole achieve the set goals. The set goals for the student for example should be to graduate with a very good grade while that of the school should be that all their students passed the qualifying examination that is have $100 \%$ success rate. Nursing and Midwifery Council of Nigeria expectation for Schools of Nursing is that they should have between $90 \%$ and $100 \%$ consistently (oral interview with Koyejo, NMCN examination unit, July, 2009). . The current advances in medical technology and demands of health services with increasingly wide spread use of such high technology and equipment requires quality training for the student nurses. From the above expressed findings and opinion it is clear that performance in Qualifying Examination is not influenced by one singular factor, what is however not clear is which of these factors contribute most effectively in influencing student nurses performance in their qualifying examination.

\section{The Concept Of Quality}

The purpose of any organization Schools of Nursing inclusive is to deliver quality services to the consumers of such services. Quality is defined as a continuous striving for excellence and a conforming to specific approaches or guidelines (Stanhope \& Lancaster, 2004). Robinson and Kish (2001) defined quality as a combination of product feature with a freedom from deficiencies. Quality according to Webster dictionary (2004) is defined as a grade or degree of excellence. Quality descriptions include among others: grade of goodness, fitness for purpose, degree of excellence, Zero defects, and right first time (Nicklin \& Kenworth 2000). They identified six elements of quality which are efficiency, effectiveness, equity, appropriatenessaccessibility and acceptability,

Quality issues are addressed in the organizations such as industries, banks hospitals, schools and so on by terms such as Quality Assurance, Quality 'Improvement, Quality Control and Total Quality Management. In relation to school do three things:-

- It sets standards for care/service.

- Evaluate teaching learning process on the basis of the set standards.

- Take action to bring about change when teaching learning process does not meet standards.

Lancaster, (1999), opined that quality improvement can be assured through approaches like credentialing, licensure, accreditations, certification, charter recognition and academic degrees. The approaches are further described in details. In this study, quality implies the degrees to which a school of nursing meet set standard as viewed from the global and national perspectives. Global perspectives as reflected by the America Nursing Association Standard (1975), English National Board Standard (1997) and World Bank School Quality indicators model (1999). The National perspective is identified in Nursing and Midwifery Council minimum requirement for establishments of Schools of Nursing (2004).

\section{SCHOOL QUALITY}

The term "School Quality" is viewed differently, measured, assessed and interpreted, in diverse manners. It is measured in terms of students' academic achievement. If students' academic performance is low, large drop out, repetition, poor morals etc. the school would be classified as a low quality school. However, it is well accepted that these factors are not the only criteria cumulating into students either good or bad academic performance.

The World Bank Publication on education (1999) defines School Quality as:

- The level of material input allocated to the school on a per student basis (resource consideration) and

- The level of efficiency with which fixed amount of these material inputs are organized and managed to raise academic achievements. On the other hand, school quality as defined by Arriagada (1982) and quoted by Sowunmi (2004) is the school specific impact on the student learning after accounting for contextual factors. It is a function of material and non-material inputs.

\section{SCHOOL QUALITY INDICATORS}

An indicator gives information of how useful, how well or effective an organization or a system is performing in terms of the achievement of its stated goals and objectives. It is a statistical measure designed to show or highlight on the nature, direction and extent of change (Onwuakpa, 1998). An indicator must have a reference point, or some other measure or standard against which is to be measured or judged, meets certain substantial and technical standards that define the kind of information they should provide and features they should measure.

Obanya (1992) pointed out that school quality indicators are quantitative and qualitative in nature. Quantitative measurement includes literacy rate, enrolment ratios, transition rate, gender distribution, 
geographical and social distribution, quality of facilities and financial investment. Qualitative indicators as expressed by Obanya (1992) describe things which effects can only be felt but not easily seen or measured. These indicators describe the original goals of education in a systematic and cumulative process of nurturing the intellectual abilities, the personal and social comportment and the development of moral and spiritual values in interpersonal and human relations with a view of improving the psychological usefulness to the person and the person's social usefulness and contribution to the society.

Two models have been identified in grouping the school quality indicators. These models are:

a) World Bank publication on education model- World Bank School Quality Indicators' Model (1991)

b) National Centre for Education Statistics on Monitoring School Quality Model. (2000)
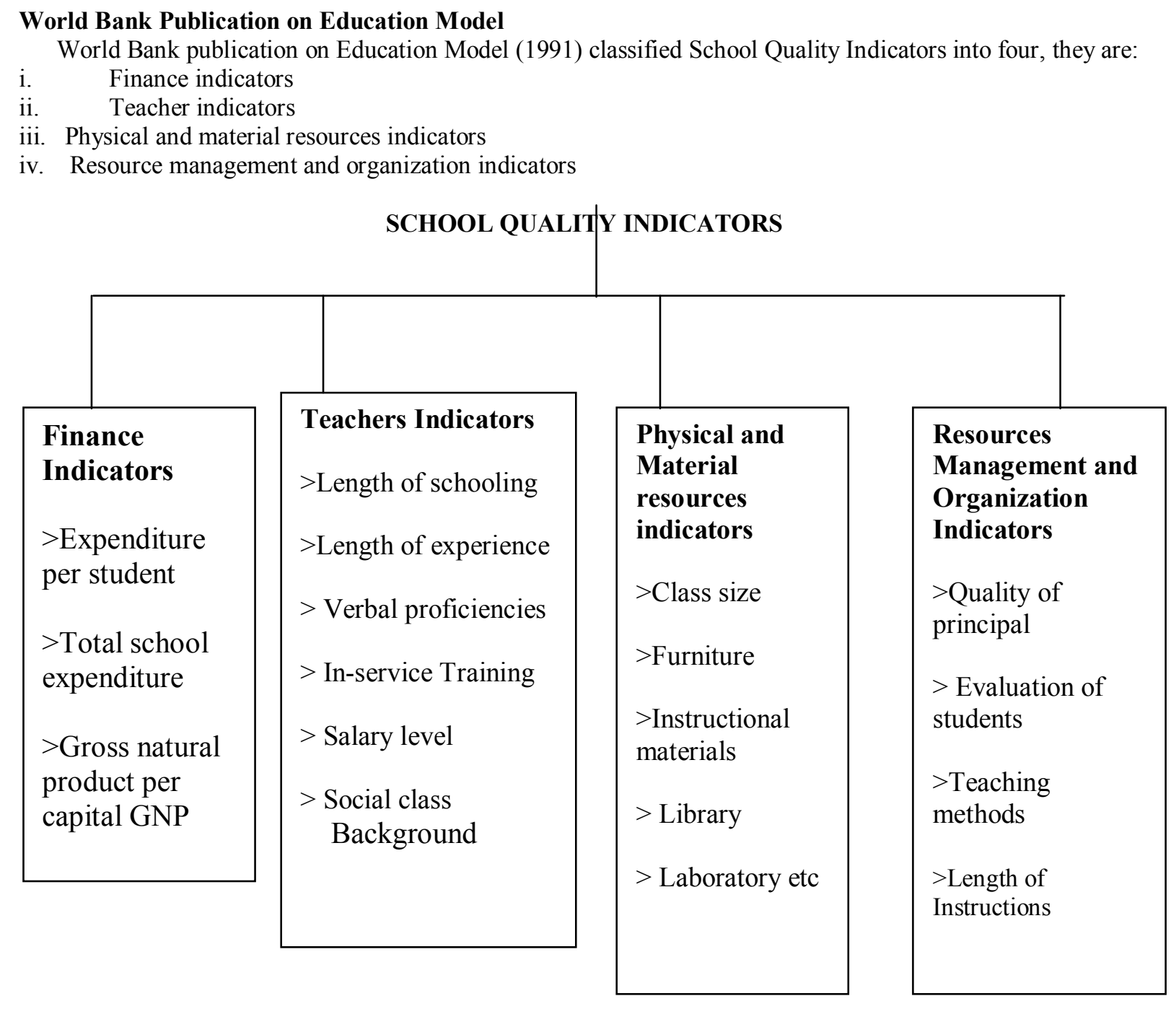

Figure 2.1: School Quality Indicators

Source: World Bank School Quality Indicators’ Model, 1991

\section{CONCEPT OF PERFROMANCE}

Performance is a multi dimensional phenomenon whose elements include effectiveness, efficiency, economy, productivity, quality and behavior. Performance can be tangible or behavioral. Effectiveness measures the extent to which an employee, a student, manager or head of an institution achieves the output requirement of his position with the emphasis not so much on "how" it is achieved but on "what" was to be achieved, that is, the results attained that was initially intended, having set a target achievable during a given period.

\subsection{STATEMENT OF THE PROBLEM}

The concept of school quality has been investigated in the field of general education with little evidence of such in nursing. High school quality so recognized in term of some carefully identified factors is 
very important for training student in any area of human endeavor and nursing is no exception. There is little or no empirical data about the school quality of Schools of Nursing and the extent to which such influence students' performance especially as these relate to theory and clinical examinations.

Documented results of student nurses in the Nursing and Midwifery Council Qualifying Examination (NMCQE) in twelve(12) Schools of Nursing in south-western states of Nigeria between 2004 \& 2008 revealed that the excellent mark of between $90 \%$ and $100 \%$ consistently which was the expectation of NMCN has not being attained. It was observed that none of the schools scored between $90 \%$ and $100 \%$ consistently even some schools scored below 50\%. Therefore whatever contribute most effectively to the nurses' training and eventual performance on the wards is of vital importance. This study investigated one of the factors suspected to have the most powerful influence on student nurses performance, that is, School Quality and see how it relates to student performance in Nursing and Midwifery Qualifying Examination.

\subsection{AIM OF THE STUDY}

The aim of the study was to find out the relationship between Schools' Quality and Students' Performance in Nursing and Midwifery Council Qualifying Examination (NMCQE).

\section{Objectives are:}

1. To explore the quality of Schools of Nursing in south-western Nigeria

2. To compare the quality and performance of Federal, State, and Mission owned Schools of Nursing.

\section{HYPOTHESES}

1. There is no significant relationship between School Quality and Students' performance in Nursing and Midwifery Council Qualifying Examination. (NMCQE)

2. There is no significant difference in scores of school quality indicators among Federal, State and Mission based school of nursing.

3. There is no significant difference in the student performance scores in Federal, State and Mission based school of Nursing.

\section{Research Design}

\section{Research Methodology}

The study is correlation study under the descriptive design. A correlation study examines the strength of relationship between two or more variables by determining how changes in one variable affect another variable or other variables. Correlation study is carried out by the use of a statistical technique known as correlation analysis.

\section{Research Setting}

The study was conducted in twelve (12) schools of nursing out of 16 schools of Nursing in SouthWestern States of Nigeria.

\section{Target Population}

The target population was sixteen (16) schools of Nursing in South-Western States of Nigeria.

\section{Sampling Technique and Sample}

There are six (6) states and sixteen (16) Schools of Nursing in South Western in Nigeria. Purposive and stratified techniques were utilized to select 12 schools of nursing out of sixteen (16) schools. The schools were stratified as federal Government (FGS), State Government (SGS) and Mission Schools (MS). Random sampling was utilized to select schools that are more than one under each of the establishing authority while purposive sampling was used to select a school that is the only one under an establishment. Altogether twelve (12) Schools of Nursing were selected from sixteen (16) which is $75 \%$ of Schools of Nursing in South Western Nigeria

\section{Instrument for Data Collection}

The instrument for data collection was researcher's designed School Quality Assessment Checklist (SQAC) using four quality indicators of World Bank School Quality Model (1991).

These are teachers' quality indicators (TQI), finance quality indicators (FQI), Physical and material resources quality indicators (PMQI), and resources management and organization quality indicators (RMOQI). These quality indicators together with information from Nursing and Midwifery Council (NMCN) requirement for accreditation of School of Nursing were utilized to prepare measurable indices used to design the school quality assessment checklist (SQAC) used to assess the Schools of Nursing under study. 


\section{Procedure for Data Collection}

A time table was drawn on how the school will be visited for data collection. The period of six weeks were used for the collection of data. The researcher visited the schools under study to explain the significant of the study and the protocol for data collection. Each of the principal was approached to provide information about the school and these information were validated with the evidences seen in the schools. The schools results were also collected from the records having obtained permission from Nursing and Midwifery Council of Nigeria (NMCN).

\section{Data Analysis}

Data from the study were analyzed using both descriptive and inferential statistics utilizing the statistical package for social sciences (SPSS). Hypotheses were tested using Pearson moment correlation coefficient. All hypotheses were tested at 0.05 level of significance. The results were presented in means, percentages and frequency distribution tables, bar chart and line graph.

\section{Result}

The results of research findings on the relationship between Schools Quality and Nursing and Midwifery Council Qualifying Examination in twelve Schools of Nursing in South-Western Nigeria for period of five years were presented in this chapter. Results were presented in tables and figures

Table 4:1 Teacher-Students' Ratio

\begin{tabular}{lccc}
\hline Schools & Total No of Teachers (T) & No of Students (S) & Teacher student ratio \\
A & 19 & 230 & $1: 12$ \\
\hline B & 17 & 183 & $1: 10$ \\
C & 20 & 143 & $1: 7$ \\
D & 12 & 109 & $1: 9$ \\
E & 15 & 132 & $1: 8$ \\
F & 16 & 169 & $1: 11$ \\
G & 10 & 130 & $1: 13$ \\
I & 7 & 108 & $1: 15$ \\
J & 7 & 139 & $1: 19$ \\
K & 11 & 150 & \\
L & 12 & & $1: 13$ \\
\hline
\end{tabular}

The table 4.3 shows number of teachers, number of students, and teacher-students ratio in the schools. $4(33.3 \%)$ schools had teacher student ratio of $1: 7$ and 1:10 while $8(66.7 \%)$ schools had teacher student ratio ranges between $1: 11$ and 1:19.

Table 4.2: Quality Indicators Scores (Raw and Percentage scores)of school categorized by their

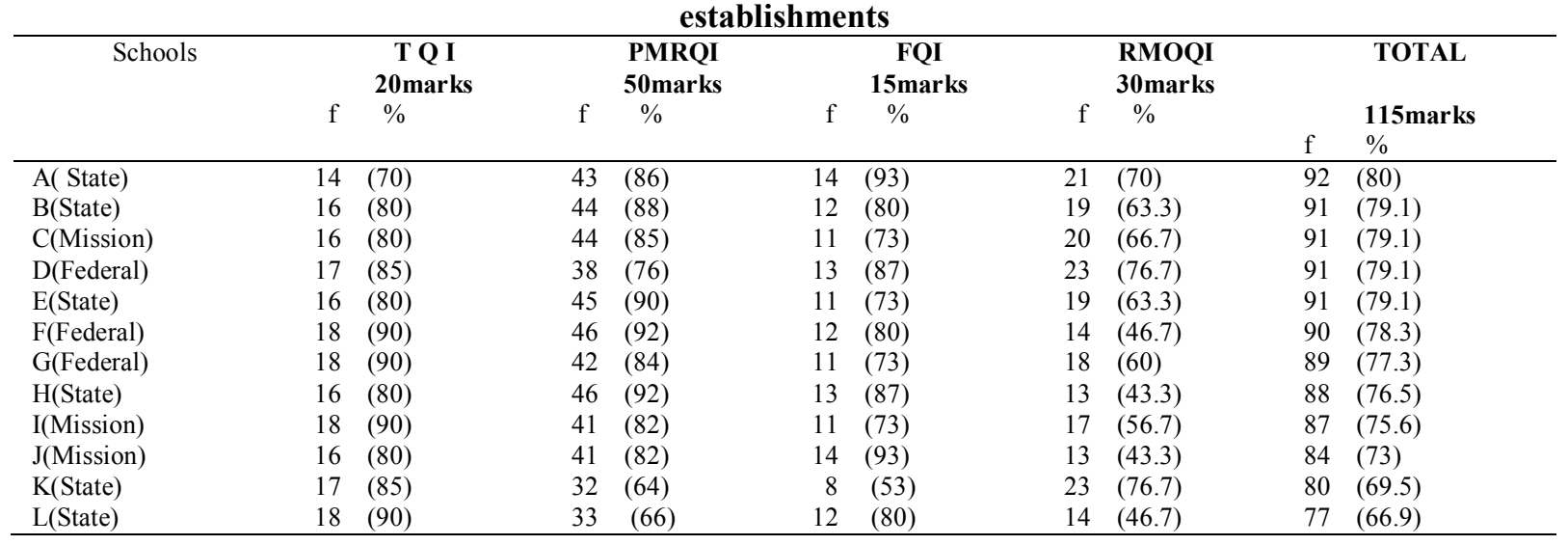

Table 4.5 Shows the range of quality indicators results obtained in 12 Schools of Nursing under study. The teacher quality indicators (TQI) obtainable scores is $20(100 \%)$. The score obtained by the schools ranges between 14(70\%) and 18(90\%) Physical and material resources indicators (PMRQI) had obtainable mark of $50(100 \%)$ while the score obtained by the schools are between $32(64 \%)$ and $46(92 \%$.). Finance quality indicators (FQI) had obtainable marks of $15(100 \%)$ and the obtained score of the schools ranged between 8 
$(53 \%)$ and $14(93 \%)$.Resources Management and organization indicators had $30(100 \%)$ as obtainable marks, the scores obtained ranges between $13(43.3 \%)$ and $23(76.7 \%)$

Table 4.3: School Performance in Nursing and Midwifery Council Qualifying Examination for 5 consecutive years $2004-2008$.

\begin{tabular}{|c|c|c|c|c|c|c|c|}
\hline Schools & $\begin{array}{l}\text { November } \\
2004\end{array}$ & $\begin{array}{l}\text { November } \\
2005\end{array}$ & $\begin{array}{l}\text { November } \\
2006\end{array}$ & $\begin{array}{l}\text { November } \\
2007\end{array}$ & $\begin{array}{l}\text { November } \\
2008\end{array}$ & Total & $\begin{array}{l}\text { Performance } \\
\text { Average }\end{array}$ \\
\hline A & 34 & 88 & 71 & 65 & 58 & 316 & 63.2 \\
\hline B & 32 & 76 & 71 & 77 & 76 & 332 & 66.4 \\
\hline $\mathrm{C}$ & 56 & 88 & 67 & 64 & 75 & 350 & 70 \\
\hline D & 67 & 91 & 77 & 94 & 95 & 424 & 84.8 \\
\hline $\mathrm{E}$ & 54 & 93 & 90 & 93 & 72 & 402 & 80.4 \\
\hline $\mathrm{F}$ & 86 & 75 & 100 & 88 & 53 & 402 & 80.4 \\
\hline G & 50 & 91 & 100 & 95 & 97 & 433 & 86.6 \\
\hline $\mathrm{H}$ & 77 & 71 & 96 & 97 & 83 & 424 & 84.8 \\
\hline I & 90 & 100 & 76 & 94 & 86 & 446 & 89.2 \\
\hline $\mathrm{J}$ & 80 & 96 & 88 & 57 & 63 & 384 & 76.8 \\
\hline K & 53 & 74 & 61 & 77 & 65 & 330 & 66 \\
\hline $\mathrm{L}$ & 43 & 61 & 64 & 71 & 73 & 312 & 62.4 \\
\hline
\end{tabular}

Table 4.3 shows the results of school performance in NMCQE between 2004 and 2008.

In 2004, the score of the schools ranges between 32\% (State) and 86\% (Federal), 2005 results ranges between $61 \%$ (State) and 100\% (Mission), 2006 scores ranges between 64\% (State) and 100\% (Federal), 2007 results ranges between 64\% (Mission) and 97\% (Federal) while 2008 ranges between 53\% (Federal) and $97 \%$ (Federal) This average scores for the 12 schools ranges between 62.4 and 89.2.

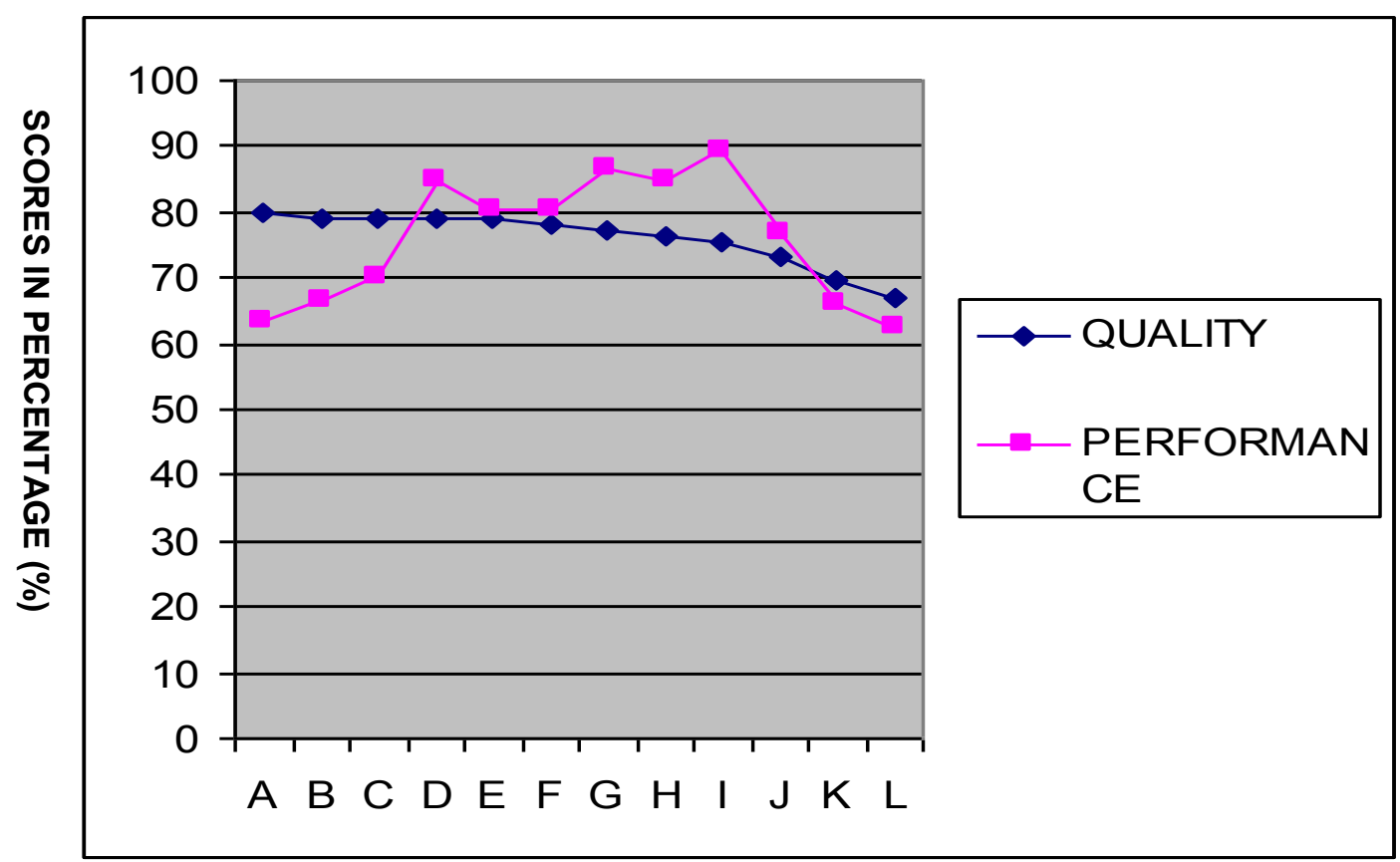

Figure 4.1 Relationship between school quality and students' performance

Fig. 4.1 Is the line graph showing the relationship between school quality and students' performance. The graph was derived from average percentage scores of both school quality and students' performance over 5years between 2004 and 2008. The graph revealed that none of the schools under study reached the expectation (between $90 \%$ \& $100 \%$ ) of NMCN.

\section{Discussion Of Findings}

Twelve (12) Schools of Nursing were studied out of 16 schools in six(6) south western states of Nigeria. Three (3) of these schools were established by Federal Government, six (6) were established by State Government while three (3) were established by Mission.

The findings revealed that only four (4) schools met requirement of 1:10 teacher students ratio Rockoff (2004) stated that the most influential force affecting students' performance is the teacher's impact which points to the 
fact that teachers should undergo qualitative educational training so as to be able to impact knowledge and influence the performance of student positively. High teachers qualification is synonymous with high student academic performance the implication of this is that teachers' qualification in Schools of Nursing in South Western Nigeria need a lot of improvement for high academic performance of $90 \%$ and above to be realizable.

The study further revealed that about $66 \%$ of the schools assessed operates serviceable internet facilities, and the other $34 \%$ have a non-serviceable or a non-functional internet facilities. In order to access up to date information on subjects/courses taught, latest handbook, modern teaching methods and practice this facility is indispensable. Burgin (2003) discovered that student quality and general performance improved in schools where the libraries spent more money per 100 students on electronic access to information (e.g. online database searching, internet access), were more likely to subscribe to online periodical services, and were more likely to subscribe to CD Rom services. It was also discovered that students in schools where networked computers linked library media centers with classrooms, labs, and other instructional sites had higher test scores.

Moreover, adequate hostel accommodation contributes in no small measure to student comfort, and by extension, their performance. The study revealed that a total of $7(58 \%)$ schools out of the 12 schools visited have adequate hostel accommodation with at least 80 well furnished rooms with enough toilets and bathroom facilities. The rest of the schools have less than these figures. This finding shows many lapses in the provision of good hostel accommodation for students: Bello (2002) [and cited by Abdul (2008)] opined that one of the factors that affects the teaching learning process and subsequently performance in examination is overcrowding. $\mathrm{He}$ argued that large class size with acute shortage of classrooms, hostel accommodation and inadequate laboratory facilities leads to overcrowding and poor performance of the learners. A lot of improvement in this area is a must for schools of Nursing in south western Nigeria if the desired academic standard is to be achieved

Good health is crucial for anybody to function properly. NMCN requirement for all Schools of Nursing are a well-staffed and functional sick bay well supplied with drugs and 24 hours service. This study revealed that out of the total twelve (12) Schools of Nursing under study only 2 schools (16\%) met the above requirement 5 schools (58\%) have a sick bay that fall below NMCN requirement. The remaining $42 \%$ do not even have a functional sick bay. This situation in grossly inadequate for excellent academic performance.

The research finding shows that of the 12 schools under study. none is autonomous, they are all controlled by the establishing authority, what this implies is that no independent decision can be taken by the school authority no matter how crucial or urgent such is. This evidently has its attendant problem especially in timely actions to relief some urgent situation. These schools need some degree of autonomy for very smooth and unhindered administration.

The findings of the study further revealed that the total school quality of all the schools under study ranges between $66.9 \%$ and $80 \%$, (table 4.2 ) while the performance scores ranges between $62.4 \%$ and $89.2 \%$ This implies that both the quality scores and performance scores are not relating at the same levels. For example school A (State) with quality score of $80 \%$ had average performance of $63.3 \%$ while school J (Mission) had quality score of $73 \%$ and performance score of $89.2 \%$. The implication of this is since quality scores and performance score are relating at the same level, there is possibility that other factors may be contributing to students' academic performance. On the other hand recent accreditation exercise might have contributed to improvement in the school quality which has not reflected on the students' performance.

The findings on the hypotheses revealed the followings:

The findings shows that School Quality (SQ) had a positive insignificant relationship with students' performance $\mathrm{p}>0.05$

Teachers' Quality indicators have positive though weak significant relationship with students' performance in their final qualifying examination.

Hypothesis three stated that there is no significant relationship between Physical and Material Resources Quality Indicators (PMRQI) and Students' Performance (SP) in NMCQE. The findings show that there is positive though insignificant relationship between Physical and Material Resources Quality Indicators and students performance $\mathrm{p}>0.05$

\section{Hypothesis One}

Hypothesis one of the study stated that there is no significant relationship between School Quality (SQ) and Students' Performance in NMCQE. The findings shows that School Quality (SQ) had a positive insignificant relationship with students' performance $\mathrm{p}>0.05$ (table 4.4). Hanushek (2005) found out that the school resources is a major predictor of student performance and competence. In the researcher's opinion for school quality to be regarded as high, it must be between $90 \% \& 100 \%$. It was observed in table 4.7 that none of the schools get to this level. This implies that school quality needs to be improved for students' performance to improve so that the two variables will have strong correlation. 


\section{Hypothesis Two}

Hypothesis two stated that there is no significant relationship between Teachers' Quality indicators (TQI) and students' performance (SP) in NMCQE.

The findings shows that Teachers' Quality indicators have positive though weak significant relationship with students' performance $\mathrm{p}>0.05$ (table 4.8). This finding directly support Rockoff (2004) who stated that the most influential force influencing student performance is the teachers impact, Smerdon \& Cromen (2004)postulated that poor teaching is one of the major factors that account for poor performance of students. The finding of this study shows a positive insignificant relationship. The researcher is of the opinion that for student academic performance to improve the quality of teachers needs to be improved. Table 4.3 shows that just 3 schools met Nursing Council standard of teacher student ratio of 1:10. It was also observed that not all the teachers are full time while some are just with RN/RM certificates. Therefore, for the relationship to be strong and significant the researcher opined the quality of be teachers be improved by getting more qualified nurse educators or send their teachers for in-service training in Nursing education.

\section{Hypothesis Three}

Hypothesis three stated that there is no significant relationship between Physical and Material Resources Quality Indicators (PMRQI) and Students' Performance (SP) in NMCQE. The findings show that there is positive though insignificant relationship between Physical and Material Resources Quality Indicators and students performance $p>0.05$ (table 4.9). This findings supports the findings of Burgin (2003) who discovered that students performance improved in schools with quality library. Hanushek (2005) concluded that the physical nature of the school, type of equipment and facilities provided, ideological climate of the school affect the performance of students. Heyman \& Damson (2003) opined that the quality of learning activities is higher with adequate and appropriate instructional material. The researchers opined that there should be provision of adequate and appropriate instructional materials, facilities and equipment for the school, which will invariably improve the student academic performance.

\section{Implications of Finding to Nursing Education}

The findings of this study have many implications to Nursing education. All hypothesis tested have positive though weak relationship with students performance. This means that there is a need to improve School Quality of Schools of Nursing so that the variable that is school quality\& will have strong relationship. None of the school performed as expected by Nursing and Midwifery Council by scoring between $90 \%$ and $100 \%$ consistently in performance score in Nursing and Midwifery Qualifying Examinations (table 4,6). Likewise none of the schools had between $90 \%$ and $100 \%$ in school quality score (table 4.5) Manpower resources within some of the Schools of Nursing fall below standard requirement. The implication of this is that a teacher will be teaching more than one course. This will reduce the teachers' efficiency at work, mastery of subject, and preparations before going to class and so on. It was discovered that performance in Federal Schools is better than in other schools. This could be because teachers are more motivated in Federal Schools in terms of pay and other incentive. The implication of this is that other schools may experience mass movement of their staff to Federal Schools to seek employment leading to depletion of capable hands in state Schools of Nursing.

\section{Summary And Conclusion}

The study was carried out to investigate the relationship between school quality and students' performance in Nursing and Midwifery council Qualifying Examination. The study findings show a positive relationship between the two variables, that is, school quality and students' performance findings also exposed some serious lapses in the schools that are directly or indirectly hindering the quality scores of these schools and by extension student s' academic performances. For instance, lapses were discovered in the quality indicator index of finance, teachers, and resources management and organizations scores. These lapses if corrected effectively can promote the school quality, and indeed improve the correlation between the variables.

Based on the result of the study, the following conclusions are made. The quality of a school (as represented by teachers' quality, finance quality, physical and material resources, quality and resources management and organizational quality) is positively related to student performance in the Nursing and Midwifery Qualifying Examination for student nurses. School quality has positive insignificant relationship on the performance of the student nurses in their qualifying examination. At 0.05 level of significance, the relationship between the school quality and performance of student is statistically not significant, implying that there is a need to improve School Quality, which will invariably improve students' performance in qualifying examinations.

Teachers' quality indicator has positive though weak relationship will be student nurses performance in their qualifying examination. At 0.05 level of significance, relationship between teachers' quality and performance of students is statistically not significant. 
The physical and material resources of a school is positively related to student performance of such school in their qualifying examination, Physical and material resources of a school has $r=.32$ positive influence on the performance of student of such schools in their qualifying examination. This relationship is not statistically significant at 0.05 significant levels.

Finance quality indicator, which is the expenditure per student in a school, the total school expenditure, sources of their funding etc has weak thought positive relationship on the student performance of such school in their final qualifying examination. Adequate financing of nursing education by the concerned authority is desirable in the opinion of the researcher.

Resources management and organization quality of a school which spell how school resources (human, material, time and finance) are managed, has negative relationship with the student performance in the qualifying examination.

Federal schools of nursing have high quality than Mission schools and Mission schools have high quality than State schools, the differences in these schools are not statistically significant at 0.05 level of significance. The performance of students in Federal school of nursing in the Nursing and Midwifery Final Qualifying Examination is better than the performance of student nurses in the Mission school of nursing in the same examination, and the performance of student nurses of State nursing schools is the least in the same examination. The difference is statistically significant.

\section{Recommendations}

On the strength of the findings of this research the followings are recommended:

* Various authorities governing Schools of Nursing should place much emphasis on improving the School Quality of Schools of Nursing generally.

* Teachers and nurse educators should be trained and retrained. Opportunity for in-service training should be made available to improve the level of educational qualification of the educators. Fund should be made available for teachers' research activities. Attendance of seminars should be encouraged.

* Physical and material resources of schools of nursing should be adequately supplied and maintained in an up to date basis. Relevant items like adequate classrooms, instructional materials, furniture, instructional media, quality library, laboratories etc should be available and functional at all time.

* Admission policy of each school/training institution should be such as to discourage fraud in the admission process, unqualified and emotionally imbalanced applicants should not be admitted under any guise or pressure. Pre-entry qualification of students and good entry scores after their entrance examination should not be compromised.

* Examination malpractices should be heavily punished and stamped out (this is important) hard

* It is noted that most schools visited has a non-functional guidance and counseling unit. Guidance and Counseling service should be a must for all training institution. This will go a long way in preparing student psychological for teaching learning process.

* A policy to regulate the salaries of health workers in the country should be formulated to arrest the flow of able hands to Federal health institution thereby leading to shortage of quality staffs in the State establishment including nursing schools

* The Nursing and Midwifery Council as the sole authority in nurses affairs in the country should make it a must to go round the accredited Nursing institutions in the country at least on a biannual bases, with the view of regulating nursing education to meet international standard and make nursing practice meet the health challenges posed by a constantly changing world.

\section{Recommendation for further research}

The relationship between library facilities of school of nursing and student academic performance could be investigated to see the strength or otherwise of library facilities on the academic performance of students nurses.

Comparative analysis of first year, first semester examination and third year hospital's final examination results to know the effect of pre-entry qualification of students on performance.

\section{REFERENCES}

[1]. Abdul, A.J. 2008. Critical Analysis of Poor Performance of Student Nurses in Final Qualify Examination: The Way Out Unpublished lecture.

[2]. Achilles, C. M. 1996. Response to Eric Hanushek: Students Achieve More in Smaller Classes. Educational leadership, 76-77.

[3]. Adelowo, E.O. 1989: The Nursing Profession in Nigeria. 2nd Ed. Lantern Books, Nigeria.

[4]. Adeniji, I.A. 1995. Resources Availability and Utilization as Correlate of School Academic Performance in SSCE. A Case Study of Some Selected Schools in Abeokuta. Unpublished Research Project. Faculty of Education U.I. Ibadan.

[5]. Ajayi, O. 2005. Continuous Assessment in Economics as a Yardstick of Determining the Performance of student and teacher in Lagos Stats Schools. Unpublished Research Project. Faculty of Education U.I. Ibadan.

[6]. American Nurses Association 2000.. Standards for Nursing Education. 
[7]. Amoo, P.O. 2006 - Teaching styles as determinants of learning outcome among Student

[8]. Level. 11(4) $300-302$.

[9]. Andrew, L. and Clerks, R. 2006. Discussion Paper - How and Why has Teacher Quality changed in Australia.

[10]. Benarld, J.A. 2001. Helping Students Become Better Learner: A case Study in Teacher Education 22(3) pp.317-335.

[11]. Biggs, J. and Collis, K. 1989. Towards a Model of School. Based Curriculum Development and Assessment Using the Solo Taxonomy Australian Journal of Education 33 (2).p151-163.

[12]. Burgin, R. 2003. An essential connection: How quality school library media programs improve student achievement in North Carolina. Retrieved Jan. 28, 2009 from RB Software and Consulting http//www.rburgin.com

[13]. Clement, S. 1998. Comprehensive Community Health Nursing, Mosby, Toronto pg. $180-181$

[14]. Coleman, M. \& Endsley, S. 1999. Quality Improvement: First Steps to Family Practice Management 6(5), 29-34.

[15]. Ehrenberg, I. and Brewer, P.2004. "Do School and Teacher Characteristics Matter? Evidence from High School and Beyond" Economics of Education Review 13 (1): 1-17.

[16]. English National Board, Midwifery and Heath visiting 2007. Standards for Approval of Higher Educational Institutions Programmes, ENB, London.

[17]. Fullan, M. \& Watson, N. 2000. School-based Management: Reconceptualizing to improve learning outcomes. School Effectiveness and School Improvement,11(4),453-474

[18]. Geleto, A.K. 2004. Factors Affecting Students' Academic Performance in Higher Education Institution.

[19]. Glass, M . \& Smith, I. 1999. Relationship between Class Size and achievement. Retrieve 10 ${ }^{\text {th }}$ January, 2009. from www.google.com

[20]. Hijaz, S.T. \& Raza-Navgi, S.M.M. 2006. Factors Affecting student's Performance; A case of private college. Bangladesh e-Journal of sociology, vol. 3rd Jan 2006.

[21]. Hanushek, E.A 2005. Assessing the Effect of School Resources on Student Performance; an update, education and policy analysis, 19(2), pp 141-64

[22]. Koyejo, K. O. 2008. Overview of Nursing Education In Nigeria (Unpublished Paper Presentation).

[23]. Lancaster, J. 1999. Nursing issues in leading and managing change. St Louis Mosby

[24]. Lorimer, L.T. 2004. The New Webster Dictionary of The English English Language $2^{\text {nd }}$ edition. New-York, Lexicon international.

[25]. Murray, C. and Thomas M. 1999. How can the Credibility of Nurse Lecturers be Improved? (1). British Journal of Nursing. (7) 8p. 490-491.

[26]. Nicklin, P.J. \& Ken-Worthy, N. 2000. Teaching \& Assessing in Nursing practice, $3^{\text {rd }}$ Ed.

[27]. Bailliere Tindall Toronto.

[28]. Nursing and Midwifery Council of Nigeria, 2008. Approved Schools Of Nursin

[29]. .http.//www.nmonigeria.org/son php retrieval $9^{\text {th }}$ July, 2008.

[30]. Nursing and Midwifery Council of Nigeria, 2004. Minimum Requirements for the Establishment

[31]. of a Schools of Nursing.

[32]. Obanya, P. 1992. Africa's education. Where is Nigeria? Institute of Education Guest Lecture Series: University of Ibadan. Valedictory Lecture.

[33]. Ogundeji, M.O. 2007. Nursing Education Reforms In Nigeria - A Paper Presented to the Nursing and Midwifery Council of Nigeria on Nursing Reforms. Unpublished Lecture. 